\title{
Famili Rhizophoraceae di Hutan Mangrove KKPD Rupat Utara Provinsi Riau Bagian I, Deskripsi Anggota
}

\author{
Rhizophoraceae Family in North Rupat KKPD Mangrove Forest Riau Province \\ Part I, Description of Members \\ Syahrial $^{1^{*}}$, Erlangga $^{1}$, Rini Tri Lestari Sembiring ${ }^{2}$, Alfi Syahrin ${ }^{2}$ \\ ${ }^{1}$ Program Studi Ilmu Kelautan, Fakultas Pertanian, Universitas Malikussaleh, Aceh, Indonesia \\ ${ }^{2}$ Mahasiswa Program Studi Ilmu Kelautan, Fakultas Pertanian, Universitas Malikussaleh, \\ Aceh, Indonesia \\ *Korespondensi: syahrial.marine@unimal.ac.id
}

\begin{abstract}
ABSTRAK
Pemantauan kekayaan spesies mangrove sangat diperlukan dalam merumuskan suatu pengelolaan dan konservasi mangrove, sehingga kajian deskripsi angota-anggota famili Rhizophoraceae dilakukan pada bulan Juli 2018 di hutan mangrove KKPD Rupat Utara. Kajian ini bertujuan untuk mengeksplorasi anggota famili Rhizophoraceae yang menyusun hutan mangrove KKPD Rupat Utara dan juga bertujuan sebagai data dasar dalam mengevaluasi ekosistem mangrove KKPD Rupat Utara dikemudian harinya. Metode yang digunakan adalah transek garis dan jelajah. Hal ini bermaksud agar spesimen yang dikumpulkan menjadi lebih lengkap. Sebanyak 5 spesies anggota Rhizophoraceae teridentifikasi sebagai penyusun hutan mangrove KKPD Rupat Utara yaitu Bruguiera gymnorrhiza, B. sexangula, Ceriops tagal, Rhizophora apiculata dan $R$. mucronata.
\end{abstract}

Kata kunci: Rhizophoraceae; hutan mangrove; KKPD Rupat Utara

\begin{abstract}
Monitoring the richness of mangrove species is very much needed in formulating management and conservation of mangroves, so a study of the description of the members of the Rhizophoraceae family was conducted in July 2018 in the mangrove forest of the North Rupat KKPD. This study aims to explore the Rhizophoraceae family members who compile the North Rupat KKPD mangrove forest and also aims as a baseline in evaluating the mangrove ecosystem of the North Rupat KKPD in the future. The method used is line transect and cruising. This means that the collected specimens become more complete. A total of 5 species of Rhizophoraceae members have been identified as compilers of the North Rupat KKPD mangrove forest namely Bruguiera gymnorrhiza, B. sexangula, Ceriops tagal, Rhizophora apiculata and $R$. mucronata.
\end{abstract}

Keywords: Rhizophoraceae; mangrove forest; North Rupat KKPD

\section{PENDAHULUAN}

Mangrove merupakan tumbuhan yang mendominasi lahan basah pesisir dan meluas ke garis lintang yang lebih tinggi (Saintilan et al., 2014) yakni diantara $30^{\circ}$ Lintang Utara hingga $30^{\circ}$ Lintang Selatan (Lugo dan
Snedaker,1974; FAO, 2007; Kuenzer et al., 2011). Luas hutan mangrove dunia hanya $2 \%$ dari permukaan bumi (Setyawan dan Winarno, 2006), tetapi menghuni lebih dari $152.000 \mathrm{~km}^{2}$ (Alongi, 2002) yang tersebar di 112 negara (FAO, 2010) dengan distribusi terbesarnya berada di daerah tropis 
maupun subtropis (Du et al., 2013; Costanza et al., 2014; Giri et al., 2015). Menurut Wang et al. (2020) mangrove merupakan tumbuhan yang sangat tahan terhadap kadar garam (salinitas) air laut, dimana keanekaragaman hayatinya terdiri dari 9 ordo, 20 famili, 27 genus dan 70 spesies (Tripathi et al., 2016) dengan Indonesia adalah negara pemilik spesies mangrove terbanyak dibandingkan negara lain (Giri et al., 2011; Ilman et al., 2016). Sedikitnya 38 spesies mangrove sejati tumbuh dan berkembang di Indonesia (Brown, 2007) dan bila dihitung/dimasukkan spesies non sejatinya, keanekaragaman hayati mangrove Indonesia lebih kurang berjumlah 89 spesies (35 spesies mangrove berpohon, 9 spesies terna, 5 spesies perdu, 9 spesies liana, 29 spesies epifit, 2 spesies parasit) (Sukardjo, 1984).

Famili Rhizophoraceae adalah salah satu keluarga mangrove yang tumbuh dan berkembang di pantai-pantai Indonesia (Saleky \& Sianturi, 2020), dimana jumlah anggota famili Rhizophoraceae secara globalnya sebanyak 25 spesies yaitu 7 spesies dari genus Bruguiera $(B$. cylindrica, $B$. exaristata, B. gymnorrhiza, B. hainessi, $B$. parviflora, $B$. sexangula, $B$. sexangula var. rhynchopetala), 6 spesies dari genus Ceriops (C. decandra, Ceriops pseudodecanda sp. nov., C. tagal, $C$. tagal var. australasica, C. tagal var. typical, C. zeppeliana blume), 10 spesies dari genus Rhizophora ( $R$. apiculata, $R$. harrisoni, $R$. lamarckii, $R$. mangle, $R$. mucronata, $R$. racemosa, $R$. samoesis, $R$. selala, $R$. stylosa, $R$. annamalayana) dan 2 spesies dari genus Kandelia (K. candel, $K$. obovata) (Sheue et al., 2003; Wu et al., 2008; Sheue et al., 2009a,b; Sheue et al., 2010). Sheue et al. (2012) menyatakan bahwa famili Rhizophoraceae tergolong atau dikenal sebagai famili magrove terkaya karena memiliki anggota (spesies) yang banyak dibandingkan dengan famili mangrove lainnya. Selain itu, masing-masing anggota famili Rhizophoraceae juga merupakan penyusun mangrove sejati (Wu et al., 2008; Rizki dan Leilani,
2017) atau dikenal dengan komponen mangrove utama yang dapat tumbuh pada tingkat kadar garam yang tinggi (berhadapan langsung dengan laut) (Rizki dan Leilani, 2017), kemudian anggota famili Rhizophoraceae secara keseluruhannya juga dapat terdiversifikasi secara ekologis (habitat) maupun morfologis (sifat) (Sheue et al., 2012). Sharma et al. (2012) menyatakan bahwa pertumbuhan daun anggota famili Rhizophoraceae terjadi di sepanjang tahun dengan waktu berbunganya pada umur ke 3 - 4 tahun (Kaliu, 2018). Sementara pertumbuhan semai (seedling) anggota famili Rhizophoraceae memiliki diameter batang kecil dari $2 \mathrm{~cm}$, sedangkan pertumbuhan anakannya (sapling) memiliki diameter batang 2 $10 \mathrm{~cm}$ dan pertumbuhan pohonnya memiliki diameter batang lebih dari 10 cm (Lasibani dan Kamal, 2010). Disamping itu, semua anggota famili Rhizophoraceae (tidak termasuk Anisophyllea) juga memiliki interpetiolar, glabrous dan caducous yang berukuran besar serta mencolok pada pucuk vegetatif maupun reproduksinya (Hou, 1958).

Terlepas dari hal di atas, Kawasan Konservasi Perairan Daerah (KKPD) Rupat Utara merupakan salah satu bentuk pengelolaan kawasan konservasi perairan yang bertujuan untuk melindungi habitat, struktur, fungsi maupun intergritas ekosistem, keragaman, kekayaan serta kepadatan atau kelimpahan spesies biota laut di Provinsi Riau, dimana luas KKPD Rupat Utara mencapai15.547 ha yang terdiri atas ekosistem mangrove (1413.58 ha) dan perairan laut (14133.50 ha). Sebelah Utara dan Barat KKPD Rupat Utara berbatasan dengan Selat Malaka, sebelah Selatan berbatasan dengan Desa Titi Akar, sedangkan sebelah Timur berbatasan dengan Selat Melaka dan Desa Tanjung Medang.

Kajian-kajian ekologi pada Kawasan Konservasi Perairan Daerah (KKPD) Rupat Utara masih belum banyak dilakukan. Begitu juga dengan deskripsi (pertelaan) dari masing-masing spesies mangrove yang menghuni 
ekosistem mangrovenya, terutama anggota famili Rhizophoraceae. Berdasarkan hal tersebut, maka kajian famili Rhizophoraceae di hutan mangrove KKPD Rupat Utara khususnya deskripsi anggota sangat perlu dilakukan. Hal ini bertujuan untuk mengeksplorasi anggota famili Rhizophoraceae yang menyusun hutan mangrove KKPD Rupat Utara. Selain itu, juga bertujuan sebagai data dasar dalam mengevaluasi ekosistem mangrove KKPD Rupat Utara dikemudian hari.

\section{METODE PENELITIAN}

\section{Waktu dan Tempat Penelitian}

Kajian dilakukan pada bulan Juli 2018 dengan lokasi penelitian terfokus pada wilayah Kawasan Konservasi Perairan Daerah (KKPD) Rupat Utara yaitu Desa Titi Akar, Suka Damai, Tanjung Medang dan Pulau Babi (Gambar 1). Stasiun 1 dan 2 berada di Desa Titi Akar, Stasiun 3 di Desa Suka Damai, Stasiun 4 di Pulau Babi serta
Stasiun 5 dan 6 berada di Desa Tanjung Medang.

\section{Alat dan Bahan Penelitian}

Alat yang digunakan dalam penelitian ini adalah rol meter, buku identifikasi mangrove, data sheet, kamera, GPS Garmin 62 series, ruler, alat tulis, kantong plastik polyethylene, gunting ranting, spidol permanen, tali rafia dan karet gelang. Sementara bahan yang digunakan adalah alkohol $70 \%$.

\section{Pengumpulan Spesimen Anggota Famili Rhizophoraceae}

Spesimen anggota famili Rhizophoraceae dikumpulkan menggunakan metode transek garis dan metode jelajah. Untuk metode transek garis, pengumpulan spesimennya dilakukan dengan membuat transek garis dan plot, dimana transek garis ditarik dari titik acuan (tegakan mangrove terluar) dengan arah tegak lurus garis pantai sampai ke daratan dan dibuat petak-petak contoh (plot) dengan ukuran $10 \times 10 \mathrm{~m}$ (Bengen, 2001). Untuk metode jelajah,
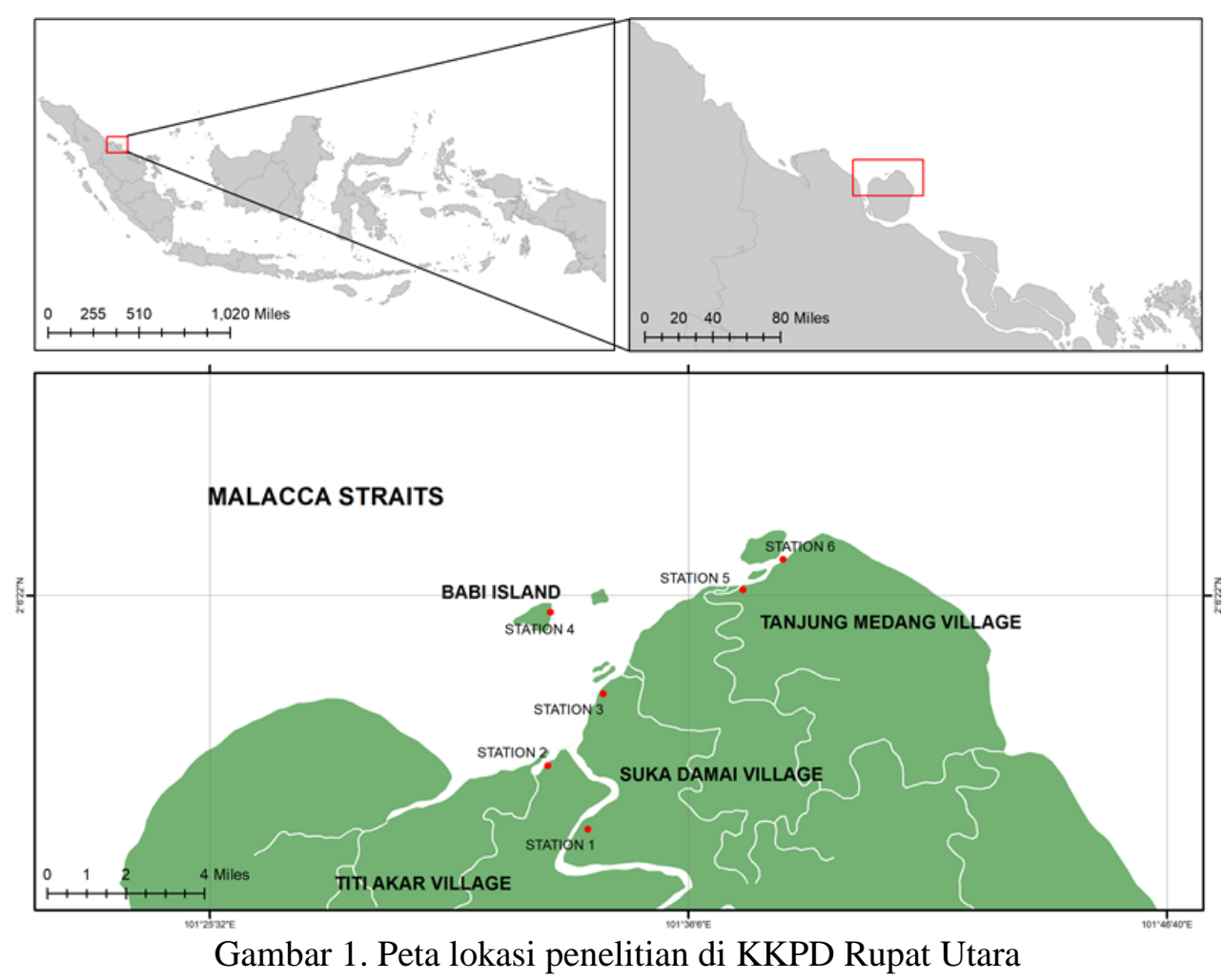
dilakukan sebagai pelengkap untuk mendapatkan spesimen yang tidak ditemukan dengan metode transek garis, sehingga dengan menggunakan kedua metode tersebut diharapkan spesimen yang dikumpulkan menjadi lebih lengkap.

Tegakan anggota famili Rhizophoraceae yang ditemukan, baik itu menggunakan metode transek garis maupun metode jelajah, masing-masing diambil organ daun, bunga serta buahnya, kemudian dimasukkan ke dalam kantong plastik polyethylene dan diberi pengawet alkohol $70 \%$ serta diikat dengan karet gelang dan diberi label. Sementara untuk organ akar maupun kulit kayunya, difoto menggunakan kamera. Spesimenspesimen anggota famili Rhizophoraceae yang telah terkumpul, selanjutnya dicocokkan dengan deskripsi dari masing-masing jenis tumbuhan mangrove famili Rhizophoraceae menurut Kitamura et al. (1997), Sudarmadji (2004), Giesen et al. (2006), Noor et al. (2006), Primavera (2009), Setyawan dan Ulumuddin (2012), Kusmana et al. (2013) dan Sosia et al. (2014).

\section{HASIL DAN PEMBAHASAN}

Hasil pengamatan di lapangan dengan menggunakan metode transek garis dan metode jelajah memperlihatkan bahwa anggota famili Rhizophoraceae yang ditemukan atau teridentifikasi di KKPD Rupat Utara sebanyak 5 spesies dengan 3 genus, dimana genus Bruguiera dan Rhizophora terdapat 2 spesies, sedangkan genus Ceriops hanya 1 spesies (Tabel 1). Menurut IUCN (2020) status global dari kelima anggota famili Rhizophoraceae di KKPD Rupat Utara tersebut tergolong least concern yaitu spesies dengan tingkat resiko kepunahannya masih sangat rendah.

\section{Bruguiera gymnorrhiza (L.) Lamk.}

Sinonim: B. capensis BI., B. conjugata (non Rhizophora conjuga L.) Merr., B. conjugata f. alba Stone, B. cylindrica (non Bl.) Hance., $B$. gymnorrhiza (with one ' $\mathrm{r}$ '), B. rhedii $\mathrm{Bl}$., B. rumphii Bl., B. wightii Bl., B. zipelii Bl., Mangium celsum Rumph., M. minus Rumph., Rhizophora gymnorrhiza L., $R$. palun., $R$. rhedii Steud., dan $R$. tinctoria Blanco (Kusmana et al., 2013; TPL, 2020). Nama lokal: tumu, lindur, tancang merah, sala-sala, totongkek, tancang, tanjang, tanjang merah, putut, tokketokke, tokke, mutut besar, tongke, tongke kecil, mangi-mangi, wako, bako, bangko, sarau, kendeka, kandeka, pertut, taheup, tenggel, tomo dan dau (Noor et al., 2006; Kusmana et al., 2013). Perawakan: pohonnya selalu hijau dengan tinggi mencapai $20-36 \mathrm{~m}$ dan diameter batangnya mencapai $60 \mathrm{~cm}$, kulit kayu luarnya berwarna abu-abu kehitaman sampai coklat (warna berubah-ubah) dan kulit kayu dalamnya berwarna merah muda hingga coklat kemerahan, permukaan kulit kayu halus hingga kasar, berlenti sel, retak-retak memanjang searah vertikal dan memiliki celah, akarnya seperti papan melebar ke samping di bagian pangkal pohon, memiliki sejumlah akar lutut dan banir kecil yang berasal dari bentukan seperti akar tunjang.

Tabel 1. Spesies anggota famili Rhizophoraceae yang ditemukan di KKPD Rupat Utara

\begin{tabular}{clll}
\hline No & \multicolumn{1}{c}{ Genus } & \multicolumn{1}{c}{ Spesies } & a Status Global \\
\hline 1 & Bruguiera & Bruguiera gymnorrhiza & Least Concern \\
2 & Bruguiera & Bruguiera sexangula & Least Concern \\
3 & Ceriops & Ceriops tagal & Least Concern \\
4 & Rhizophora & Rhizophora apiculata & Least Concern \\
5 & Rhizophora & Rhizophora mucronata & Least Concern \\
\hline
\end{tabular}

aUCN (2020) 
Daun: tunggal, permukaannya berwarna hijau tua, bawah permukaannya berwarna hijau kekuningan dengan bercak-bercak hitam (ada juga yang tidak), tulang daun kadangkala berwarna kemerah-merahan, tata daunnya bersilangberhadapan (opposite), ujungnya runcing, bentuknya elips sampai bulat panjang, panjang daun $4.5-15 \mathrm{~cm}$, lebar daun $4-22 \mathrm{~cm}$. Bunga: formasinya soliter, rangkaian bunga lebar dan tunggal di ketiak daun, bunga bergelantungan, kelopak berjumlah $10-14$ yang berbentuk genta danberwarna merah hingga merah muda, panjang kelopak $3-5 \mathrm{~cm}$, ujung mahkota runcing dan sedikit pendek daripada kelopaknya serta memiliki warna putih hingga kecoklatan jika sudah tua, masing-masing terdiri atas 3 tangkai benang sari dengan benang sarinya berpasangandan melekat pada daun mahkota serta panjang tangkai bunganya mencapai $9-25 \mathrm{~mm}$. Buah: berbentuk bulat/melingkar spiral, bundar melintang, diameter buah $1.5-2 \mathrm{~cm}$, panjang buah $7-15 \mathrm{~cm}$, permukaan buah licin, hipokotilnya halus dan lurus, mirip cerutu dan berwarna hijau tua sampai ungu kecoklatan dengan ujungnya tumpul dan ada bercak-bercak coklat, serta kelopaknya menyatu saat buah jatuh. Habitat: tanah basah yang sedikit berpasir, tumbuh di daerah mangrove bagian tengah sampai bagian dalam dan umumnya di daerah yang aerasinya sangat baik, merupakan jenis yang dominan pada hutan mangrove tinggi, merupakan ciri dari perkembangan tahap akhir dari hutan pantai dan tahap awal dalam transisi menjadi tipe vegetasi daratan, dapat tumbuh di areal yangbersalinitas rendah maupun kering, sangat toleran terhadap daerah terlindung maupun yang mendapat sinar matahari langsung, tumbuh juga pada tepi daratan dari ekosistem mangrove dan di sepanjang tambak serta sungai pasang surut hingga payau, kadang-kadang juga ditemukan di pinggir sungai yang kurang terpengaruh oleh air laut, ditemukan berhadapan langsung dengan laut apabila terjadi erosi pada lahan di depannya, substrat tumbuhnya terdiri dari lumpur, pasir dan kadang-kadang tanah gambut hitam, regenerasinya seringkali dalam jumlah terbatas, bunga dan buahnya terdapat di sepanjang tahun (Sudarmadji, 2004; Noor et al., 2006; Kusmana et al., 2013). Penyebaran: dari Afrika Timur dan Madagaskar hingga Sri Lanka, Malaysia, Indonesia menuju wilayah Pasifik Barat dan Australia Tropis (Noor et al., 2006).

\section{Bruguiera sexangula (Lour.) Poir.}

Sinonim: B. australis A.Cunn. ex Arn., B. eriopetala Wight \& Arn., B. oxyphylla Miq., B. parietosa Griff., $B$. sexangula var. rhynchopetala W.C.Ko dan Rhizophora sexangula Lour. (TPL, 2020). Nama lokal: bosing, busing, busung, mata buaya, tumu, bakau tampusing, tanjang, lindur, ting, tongke perampuan, ai bon, tancang sukun dan mutut kecil (Noor et al., 2006; Sosia et al., 2014). Perawakan: pohon tingginya dapat mencapai $30 \mathrm{~m}$ yang selalu hijau, kulit kayu halus hingga kasar dan berwarna coklat muda hingga abu-abu gelap, memiliki sejumlah lentisel yang berukuran besar, pangkal batang membengkak, memiliki akar lutut dan kadang-kadang akar papan. Daun: tunggal dan agak tebal, berkulit serta memiliki bercak hitam di bagian bawahnya, letak daun tersusun berlawanan, bentuk daun elips, ujungnya meruncing, panjang daun $6-16 \mathrm{~cm}$ dan lebar daun $3-6 \mathrm{~cm}$ dengan warnanya hijau kekuningan. Bunga: formasinya soliter (1 bunga per tandan), terletak di ketiak daun, kelopak bunganya berjumlah $10-14$, berwarna hijau kekuningan atau kemerahan atau kecoklatan, daun mahkotanya berjumlah $10-11$ dengan panjangnya $15 \mathrm{~mm}$ dan berwarna putih (jika tua berwarna kecoklatan) serta kadang berambut halus pada tepinya. Buah: berbentuk bulat, diameternya $1.5-$ $2 \mathrm{~cm}$, berwarna hijau sampai ungu kecoklatan, diameter hipokotilnya $1-1.5$ $\mathrm{cm}$ dan panjang hipokotilnya $6-12 \mathrm{~cm}$ dengan kedua ujung hipokotilnya menyempit. Habitat: tanah basah dan sedikit berpasir, tumbuh di sepanjang jalur air dan tambak pantai, ditemukan 
pada berbagai tipe substrat yang tidak sering tergenang, toleran terhadap kondisi air asin, payau maupun tawar (Sudarmadji, 2004; Noor et al., 2006; Sosia et al., 2014). Penyebaran: dari India, seluruh Asia Tenggara (termasuk Indonesia) hingga Australia Utara (Noor et al., 2006).

\section{Ceriops tagal (Perr.) C. B. Rob.}

Sinonim: Bruguiera arnottiana Wight ex Arn., B. timoriensis Wight \& Arn., C. boviniana Tul., C. candolleana Arn., C. candolleana var. sasakii Hayata, C. candolleana var. spathulata Blume, $C$. forsteniana Blume, C. globulifera Boreau ex Tul., C. lucida Miq., C. lucida var. latifolia Miq., $\quad$ C. lucida var. subspathulata Miq., C. mossambicensis Klotzsch, $C$. pauciflora Benth., $C$. somalensis Chiov., C. timoriensis Domin, C. timoriensis (DC.) C.A. Gardner, Rhizophora tagalPerr., R. timoriensis DC. dan R. candel Blanco (TPL, 2020). Nama lokal: tengar, tengah, tangar, tingih, tingi, palun, parun, bido-bido, lonro, mentigi, tinci, mange darat dan wanggo (Noor $e t$ al., 2006). Perawakan: perdu sampai pohon, tingginya dapat mencapai $3-25$ $\mathrm{m}$, kulit kayu berwarna abu-abu kecoklatan dan bagian bawahnya sedikit mengelupas, permukaan kulit kayu halus dengan pangkalnya menggelembung serta pohonnya seringkali memiliki akar tunjang yang kecil. Daun: tunggal dengan letaknya berlawanan, berwarna hijau muda sampai tua dan mengkilap, bagian tepi daunnya seringkali melengkung/melingkar ke dalam, ujung daunnya membundar/membulat seperti bulat telur terbalik hingga elips, panjang daun $1-10 \mathrm{~cm}$, lebar daun $2-3.5 \mathrm{~cm}$. Bunga: formasi bunganya berkelompok ( 5 - 10 bunga per kelompok) yang berada di ujung tandan, gagang bunga panjang dan tipis, memiliki resin pada ujung cabang baru atau pada ketiak cabang yang lebih tua, letak bunganya di ketiak daun, tangkai bunganya panjang, kelopak bunga berjumlah 5 dan berwarna hijau dengan panjangnya $4-5 \mathrm{~mm}$, daun mahkotanya berjumlah 5 yang berwarna putih kecoklatan, tangkai benang sarinya lebih panjang dari kepala sari dan kepala sarinya tumpul. Buah: berbentuk bulat dengan panjangnya $1.5-2 \mathrm{~cm}$, tabung kelopak melengkung, warna buahnya merah kecoklatan, hipokotil mirip pensil, panjang hipokotil $4-25 \mathrm{~cm}$ dan diameternya $8-12 \mathrm{~mm}$, memiliki alur, sedikit berbintil pada permukaannya, berkulit halus, agak menggelembung dan pendek serta leher kotilodonnya menjadi kuning jika sudah matang/dewasa. Habitat: tanah liat yang agak kering dan sedikit berpasir, membentuk belukar yang rapat pada pinggir daratan dari hutan pasang surut dan/atau areal yang tergenang oleh pasang tinggi dengan tanah memiliki sistem pengeringan yang baik dan juga terdapat di sepanjang tambak serta biasanya berdampingan dengan $C$. decandra (Sudarmadji, 2004; Noor et al., 2006). Penyebaran: dari Mozambik hingga Pasifik Barat, termasuk Australia Utara, Malaysia dan Indonesia (Noor et al., 2006).

\section{Rhizophora apiculata Bl.}

Sinonim: Mangium candelarium Rumph., $R$. candelaria DC., $R$. conjugata (non Linne) Arn., $R$. lamarckii dan $R$. mangle (non Linne) (Kusmana et al., 2013; TPL, 2020). Nama lokal: bangka minyak, bakau minyak, bakau tandok, bakau akik, donggo akit, jankar, abat, parai (Sarbei, Bintuni), kajang-kajang, tokei (Palopo), bakau (Riau, Makasar), bakau bini (Tarakan, Kalimantan Timur), tongke kecil (Ambon), mangi-mangi (Sorong), bakau leutik, bakau kacang, bakau putih, bakau puteh, tanjang wedok, tongke busar, lalano, wako, jangkah, slengkreng, tinjang dan lenro (Noor et al., 2006; Kusmana et al., 2013; Sosia et al., 2014). Perawakan: pohon dengan tingginya mencapai $15-35 \mathrm{~m}$ dan berdiameter $55 \mathrm{~cm}$, batangnya berkayu, silindris, kulit kayu luar berwarna abuabu kecoklatan dan bercelah vertikal, akar udara muncul dari percabangannya, memiliki perakaran yang khas dengan ketinggian mencapai $5 \mathrm{~m}$ dan kadangkadang memiliki akar udara yang keluar dari cabangnya juga. Daun: susunan daunnya tunggal, bersilangan (opposite), 
bentuk daunnya elips dan menyempit dengan ujungnya runcing/tajam, permukaan daun halus dan mengkilap, berbentuk lonjong, panjang daunnya mencapai $3-19 \mathrm{~cm}$, lebar daunnya $3.5-$ $8 \mathrm{~cm}$, pangkal daun berbentuk baji, berwarna hijau tua dengan hijau muda pada bagian tengahnya, permukaan bawah tulang daun berwarna kemerahan, terdapat bintik hitam kecil yang menyebar di seluruh permukaan bawah daunnya, tangkai daun pendek dengan panjangnya sekitar $1-3.5 \mathrm{~cm}$ dan berwarna kemerahan. Bunga: biseksual, terletak di ketiak daun, kepala bunga kekuningan, umumnya tersusun atas 2 bunga per kelompok pada tangkai bunga yang kokoh dan pendek (panjang hingga $1.4 \mathrm{~cm}$ ), kelopak bunganya berjumlah 4 dan berwarna coklat/hijau kekuningan serta melengkung, mahkotanya berjumlah 4 dengan panjangnya $9-11$ $\mathrm{mm}$, tidak mempunyai rambut, berwarna hijau hingga keputihan, putik pertamanya terbelah 2 dengan panjangnya $0.5-1$ $\mathrm{mm}$, benang sari berjumlah 12 , tidak bertangkai dan berwarna coklat. Buah: bersifat vivipari, warnanya coklat, hipokotilnya silindris dengan diameternya $1-2 \mathrm{~cm}$ serta panjangnya mencapai $18-38 \mathrm{~cm}$, bagian ujung hipokotilnya sedikit berbintik-bintik danberwarna hijau keunguan, berisi satu biji fertil, kotiledonnya berwarna merah jika sudah matang/dewasa dengan permukaan buahnya kasar. Habitat: di tanah basah, berlumpur dan berpasir serta tumbuh subur pada daerah muara sungai yang memiliki lumpur lembut/halus, yang dalam dan tergenang saat pasang normal, tetapi umumnya tumbuh di tanah yang berlempung, berhumus dan beraerasi baik, tingkat dominasinya dapat mencapai $90 \%$ dari vegetasi yang tumbuh di suatu lokasi, menyukai perairan pasang surut yang memiliki pengaruh masukan air tawar yang kuat secara permanen, percabangan akarnya dapat tumbuh secara abnormal karena adanya gangguan kumbang dan kepiting (Sudarmadji, 2004; Noor et al., 2006; Kusmana et al., 2013; Sosia et al., 2014). Penyebaran: Sri Lanka, seluruh Malaysia dan Indonesia hingga Australia tropis dan Kepulauan Pasifik (Noor et al., 2006).

\section{Rhizophora mucronata Lamk.}

Sinonim: Mangium candelarium Rumphius., $R$. candelaria Wight \& Arn., $R$. latifolia Miq., R. longissima Blanco., $R$. macrorrhiza Griff., $R$. mangle (non Linne) Roxb., dan $R$. mucronata var. typica Schimp (Kusmana et al., 2013; TPL, 2020). Nama lokal: bakau, bako gundul, bakau genjah, bakau bandul, bakau hitam, tanjang lanang, tokke-tokke (Palopo), bakao (Makasar), bakau laki (Tarakan Kaltim), blukap (Sarbei Bintuni), tongke besar, lului, bakaubakau, wako, bangko, bako, bangka itam, dongoh korap, bakau korap, bakau merah, jankar, lenggayong, belukap dan lolaro (Noor et al., 2006; Kusmana et al., 2013; Sosia et al., 2014). Perawakaan: tinggi pohonnya mencapai $20-30 \mathrm{~m}$ (jarang melebihi $30 \mathrm{~m}$ ), berdiameter 35 $70 \mathrm{~cm}$, kulit batangnya kasar, memiliki celah horizontal, berwarna abu-abu kehitaman, akar tunjang serta akar udara tumbuh dari percabangan bagian bawahnya. Daun: berbentuk elips sampai bulat panjang, berkulit, berdaun lebar, panjangnya $10-22 \mathrm{~cm}$, lebar $8-11 \mathrm{~cm}$, ujungnya meruncing (acute) dan berduri (mucronatus), bagian atas daun berwarna hijau tua serta bagian bawah daunnya berwarna hijau muda kekuning-kuningan, permukaan bawah tulang daun berwarna kehijauan dan terdapat bintik-bintik hitam yang tidak merata, panjang tangkai daunnya $3-4.5 \mathrm{~cm}$, letak daunnya berhadapan dan bersilangan (opposite), komposisi daunnya tunggal serta pangkal daunnya cunneate, gagang daun berwarna hijau, panjang gagang daun 2.5 $-5.5 \mathrm{~cm}$ dan pinak daunnya terletak pada pangkal gagang daun (berukurannya 5.5 - $8.5 \mathrm{~cm}$ ). Bunga: bersifat biseksual, berdiameter $3-4 \mathrm{~cm}$, panjangnya $1.5-2$ $\mathrm{cm}$ yang meruncing pada bagian ujungnya, gagang kepala bunganya berbentuk cagak, tersusun atas $4-8$ bunga tunggal (tersusun dua-dua), bergantung/terletak di ketiak daun, kelopaknya berjumlah 4, berwarna kuning gading hingga hijau kekuningan, 
panjangnya $13-19 \mathrm{~mm}$, jumlah mahkotanya 4, berwarna putih, berambut/berbulu di bagian pinggir dan belakangnya, kemudian benang sarinya berjumlah 8 yang berukuran pendekpendek dan tidak bertangkai serta panjang tangkai putiknya $1-2 \mathrm{~mm}$ dengan ujungnya terbelah dua. Buah: bersifat vivipari, berbentuk hipokotil (silindris), di permukaannya terdapat bintik-bintik, warnanya hijau kekuningan, berdiameter $2-2.5 \mathrm{~cm}$ dengan panjangnya mencapai $90 \mathrm{~cm}$, daun kelopaknya (calyx) tidak luruh serta leher kotiledonnya berwarna kuning ketika matang/dewasa. Habitat: tumbuh subur pada daerah muara sungai yang memiliki lumpur halus, dalam dan sedikit berpasir serta mudah beradaptasi di ketinggian pasang air laut, jarang sekali tumbuh pada daerah yang jauh dari air pasang surut dengan pertumbuhan optimalnya terjadi pada areal yang tergenang maupun pada tanah yang kaya akan humus, sering ditemukan di areal yang sama dengan $R$. apiculata tetapi lebih toleran terhadap substrat yang lebih keras dan berpasir, tumbuhnya secara berkelompok, merupakan salah satu jenis mangrove yang paling penting dan tersebar luas, perbungaannya terjadi di sepanjang tahun, anakannya seringkalidimakan oleh kepiting yang menyebabkan pertumbuhannya menjadi terhambat (Sudarmadji, 2004; Noor et al., 2006; Kusmana et al., 2013; Sosia et al., 2014). Penyebaran: Afrika Timur, Madagaskar, Mauritania, Asia Tenggara, seluruh Malaysia dan Indonesia, Melanesia serta Mikronesia (Noor et al., 2006).

\section{KESIMPULAN}

Anggota famili Rhizophoraceae yang ditemukan di Kawasan Konservasi Perairan Daerah (KKPD) Rupat Utara sekitar 20\% dari jumlah anggota Rhizophoraceae global yaitu 2 spesies dari genus Bruguiera, 1 spesies dari genus Ceriops dan 2 spesies dari genus Rhizophora.

\section{UCAPAN TERIMA KASIH}

Ucapan terima kasih disampaikan kepada Balai Pengelolaan Sumber Daya Pesisir dan Laut (BPSPL) Padang yang telah memfasilitasi penulis dalam melakukan penelitian ini. Selanjutnya ucapan terima kasih juga disampaikan kepada UPTD Perikanan Rupat Utara dan BMC Universitas Riau, sehingga terselesainya penelitian ini dengan lancar.

\section{DAFTAR PUSTAKA}

Alongi, D. M., 2002. Present state and future of the world's mangrove forests. Environmental Conservation. 29(3): $331-349$.

Bengen, D. G., 2001. Pengenalan dan Pengelolaan Ekosistem Mangrove. Pusat Kajian Sumberdaya Pesisir dan Lautan IPB. Bogor, Indonesia. IPB Press.

Brown, B., 2007. Resilience Thinking Applied to the Mangroves of Indonesia. IUCN \& Mangrove Action Project. Yogyakarta, Indonesia. $53 \mathrm{p}$.

Costanza, R., de Groot, R., Sutton, P., van der Ploeg, S., Anderson, S. J., Kubiszewski, I., Farber, S., Turner, R. K., 2014. Changes in the global value of ecosystem services. Global Environmental Change. 26: $152-158$.

Du, J., Yan, C., Li, Z., 2013. Formation of iron plaque on mangrove Kandalar obovata (S.L.) root surfaces and its role in cadmium uptake and translocation. Marine Pollution Bulletin. 74(1): 105 - 109.

[FAO] Food and Agriculture 
Organization., 2007. The World's Mangroves 1980 2005: A Thematic Study Prepared in The Frameworkof The Global Forest Resources Assessment 2005. Roma, Itali.

[FAO] Food And Agriculture Organization., 2010. Global Forest Resources Assessment 2010: Main Report. Roma, Itali.

Giesen, W., Wulffraat, S., Zieren, M., Scholten, L., 2006. Mangrove Guidebook for Southeast Asia. FAO and Wetlands International.

Giri, C., Ochieng, E., Tieszen, L. L., Zhu, Z., Singh, A., Loveland, T., Masek, J., Duke, N., 2011. Status and distribution of mangrove forests of the world using earth observation satellite data. Global Ecology and Biogeography. 20(1): 154 - 159.

Giri, C., Long, J., Abbas, S., Murali, R. M., Qamer, F. M., Pengra, B., Thau, D., 2015. Distribution and dynamics of mangrove forests of South Asia. Environmental Management. 148: 101 - 111.

Hou, D., 1958. Rhizophoraceae. Dalam: C. G. G. J. van Steenis (ed.), Flora Malesiana, ser. 1, Vol. 5. Noordhoff- Kolff N. V., Djakarta, Indonesia. pp. 429473.

Ilman, M., Dargusch, P., Dart, P., Onrizal., 2016. A historical analysis of the drivers of loss and degradation of Indonesia's mangroves. Land Use Policy. 54: $448-459$.

[IUCN] International Union for
Conservation of Nature., 2020. The IUCN Red List of Threatened Species. Diakses dari http://www.iucnredlist.org/.

Kaliu, S., 2018. Struktur vegetasi mangrove dan fekunditas di Desa Terapungmawasangka Sulawesi Tenggara. Saintifik. 4(1): $31-38$.

Kitamura, S., Chairil, A., Amalyos, C., Shigeyuki, B., 1997. Buku Panduan Mangrove di Indonesia - Bali dan Lombok. Okinawa, Jepang. JICA.

Kuenzer, C., Bluemel, A., Gebhardt, S., Vo Quoc, T., Dech, S., 2011. Remote sensing of mangrove ecosystems: A review. Remote Sensing. 3(5): $878-928$.

Kusmana, C., Valentino, N., Mulyana, D., 2013. Flora Mangrove di Kawasan Hutan Angke Kapuk Jakarta Utara, Provinsi DKI Jakarta. Bogor, Indonesia. PT. Kapuk Naga Indah dan Fakultas Kehutanan Institut Pertanian Bogor.

Lasibani, S. M., Kamal, E., 2010. Pola penyebaran pertumbuhan "propagul" mangrove Rhizophoraceae di kawasan pesisir Sumatera Barat. Mangrove dan Pesisir. 10(1): 33 -38 .

Lugo, A. E., Snedaker, S. C., 1974. The ecology of mangroves. Annual Review of Ecology and Systematics. 5: $39-64$.

Noor, Y. R., Khazali, M., Suryadiputra, I. N. N., 2006. Panduan Pengenalan Mangrove 
di Indonesia. Bogor, Indonesia.

Primavera, J. H., 2009. Field Guide to Philippine Mangroves. Philippine. The Philippine Tropical Forest Conservation Foundation and The Zoological Society of London.

Rizki, Leilani, I., 2017. Etnofarmakologi tumbuhan familia Rhizophoraceae oleh masyarakat di Indonesia. Bioconcetta. 3(1): $51-60$.

Saintilan, N., Wilson, N., Rogers, K., Rajkaran, A., Krauss, K. W., 2014. Mangrove expansion and salt marsh decline at mangrove poleward limits. Global Change Biology. 20(1): 147 - 157.

Saleky, D. Sianturi, R. 2020. Litterfall Production Of Mangrove. AGRICOLA. 10, 2: 58-65.

Setyawan, A. D., Ulumuddin, Y. I., 2012. Species diversity of Rhizophora in Tambelan Islands, Natuna Sea, Indonesia. Biodiversitas. 13(4): $172-177$.

Setyawan, A. D., Winarno, K., 2006. Pemanfaatan langsung ekosistem mangrove di Jawa Tengah dan penggunaan lahan di sekitarnya; kerusakan dan upaya restorasinya. Biodiversitas. 7(3): $282-291$.

Sharma, S., Kamruzzaman, M., Hoque, A. T. M. R., Hagihara, A., 2012. Leaf phenological traits and leaf longevity of three mangrove species (Rhizophoraceae) on Okinawa Island, Japan. Oceanography. 68(6): $831-840$.
Sheue, C. R., Liu, H. Y., Yong, J. W. H., 2003. Kandelia obovata (Rhizophoraceae), a new mangrove species from Eastern Asia. Taxon. 52: 287 - 294.

Sheue, C. R., Liu, H. Y., Tsai, C. C., Rashid, S. M. A., Yong, J. W. H., Yang, Y. P., 2009a. On the morphology and molecular basis of segregation of two species Ceriops zippeliana Blume and C. decandra (Griff.) Ding Hou (Rhizophoraceae) from Southeastern Asia. Blumea. 54: $220-227$.

Sheue, C. R., Yang, Y. P., Liu, H. Y., Chou, F. S., Chang, S. C., Saenger, P., Mangion, C. P., Wightman, G., Yong, J. W. H., Tsai, C. C., 2009b. Reevaluating the taxonomic status of Ceriops australis (Rhizophoraceae) based on morphological and molecular evidence. Botanical Studies. 50: 89 - 100.

Sheue, C. R., Liu, H. Y., Tsai, C. C., Yang, Y. P., 2010. Comparison of Ceriops pseudodecanda sp. nov. (Rhizophoraceae), a new mangrove species in Australasia, with related species. Botanical Studies. 51: $237-248$.

Sheue, C. R., Chen, Y. J., Yang, Y. P., 2012. Stipules and colleters of the mangrove Rhizophoraceae: Morphology, structure and comparative significance. Botanical Studies. 53: $243-254$.

Sosia, Yudasakti, P., Rahmadhani, T., Nainggolan, M., 2014. Mangroves Siak dan Kepulauan Meranti. Jakarta, Indonesia. 
Energi Mega Persada Malacca Strait SA.

Sudarmadji., 2004. Deskripsi jenisjenis anggota suku Rhizophoraceae di hutan mangrove Taman Nasional Baluran Jawa Timur. Biodiversitas. 5(2): $66-70$.

Sukardjo, S., 1984. Ekosistem mangrove. Oseana. 9(4): $102-$ 115 .

[TPL] The Plant List. (2020). Diakses dari http://www.theplantlist.org/.

Tripathi, R., Shukla, A. K., Shahid, M., Nayak, D., Puree, C., Mohanty, S., Raja, R., Lal, B., Gautam, P., Bhattacharyya, P., Panda, B. B., Kumar, A., Jambhulkar, N. N., \& Nayak, A. K. (2016). Soil quality in mangrove ecosystem deteriorates due to rice cultivation. Ecological Engineering. 90: 163 - 169.

Wang, Y., Lee, J., Werber, J. R., \& Elimelech, M. (2020). Capillarydriven desalination in a synthetic mangrove. Science Advances. 6(eaax5253): 1 - 9 .

Wu, Y., Chung, A., Tama, N. F. Y., Pia, N., \& Wong, M. H. (2008). Constructed mangrove wetland as secondary treatment system for municipal wastewater. Ecological Engineering. 34(2): 137 - 146. 
